\title{
Disruption of Albanian-Soviet Relations
}

\section{Phd Research Student. Brisejda Lala}

\section{Doi:10.5901/ajis.2014.v3n3p340}

History and Geography

brisejda.lala@gmail.com

\section{Abstract}

THEME: "Disruption of Albanian-Soviet Relations" aims at presenting a part of the history of Albanian people as well as the soviet influence in the internal and external policy of our country. The relations between these two countries, whose relations where extended up to 12 years, are characterized by the close unity in the first decade as well as the divergences of the last few years. Our country, Albania, and its internal and external policies were oriented towards the communist camp, and at that time "Stalinism" was the best example to be followed. The external policy of this place changed after the death of Stalin, this was reflected even in the policy which would have been followed by the state. Nikita Khrushchev, the Stalin's successor, followed the steps towards the "destalinization" and the reduction of the tensions with the West Europe countries. These policies followed by Hrushov contradicted the interests of the Albanian leader, Enver Hoxha, who was obliged to renounce from lots of political posts in order to punish the cult of personality. In 1959 the communist leader, Khrushchev, visited Albania, but this visit flustered even more the issues between these two countries. In 1960 the relations between them were irreparable, and in 1961 they decided to disconnect their diplomatic relations. Lets highlight the reasons that pushed Enver Hoxha toward the great Russian country and the reasons of this immediate disconnection of these diplomatic relations. These will be my main issues that I will work on.

Keywords: Stalinism, destalinisation, cult of personality, ect.

\section{1. "Disruption of Albanian-Soviet Relations"}

In the 1948-1961 Albanian - Soviet relations were intensive, even though they had been distinguished from continuous fluctuations and many controversies during the last years. When the Union of Soviet Socialist Republics broke down the relations with Yugoslavia, losing one of the eminent alliances and an important way out to Adriatic Sea, it extended it policies into Albania. On the other hand the government of Albania was trying to establish direct relations with the main power of the Eastern Bloc, BS, because before1948 Albania did not have any favorable opportunity to secede from the Yugoslav occupation, thus this was the perfect moment. Albania was a small and a poor country, a reason which made it easily handled in international relations. Its geographical position made it an important geopolitical country and using this country the Soviet Union could easily control almost all the Albanian coast. As a result of the Soviet - Yugoslavia split, the relations between Albania and the Soviet Union became quite close. During Stalin's leadership, Albania was trying to follow in every aspect of life the Marxist - Leninist ideology and tried to copy Stalin policy. Our small country found the necessary economic and political support to build up the country again which was destroyed by the war. But the Albanian leadership knew very well that to achieve all this they had to obey to the Soviets' wishes. These good relations would not last for too long, until the controversies between Enver Hoxha and Nikita Khrushchev would led into the disruption of diplomatic relations between the two countries in 1961.

After 1953, Albanian - Soviet relations seem to improve. "Only a few months after Stalin's death, relations between two countries became very close so the first embassies rose with their own diplomatic representatives" ("Zëri i Popullit", Newspaper, 1953). But the first divergences would soon appear. With the leading of Nikita Khrushchev the relations between Albania and Soviet Union would start a new phase, where the close friendship had been replaced by many disputes. In fact the disruption of relations did not happen within a month or even a year, as it would be alleged later by the two dictators, but it was a long process which began in 1956, the same year when Nikita Khrushchev tried to modernize the domestic and foreign policies of Soviet Union. This change would affect directly in Communist countries policies.

Even though in June 1953 Hoxha visited Moscow, he will meet the new leader of Soviet Union only after one year and where the situation inside the Communist Party was calm."In June 1954, a few months after the Khrushchev's denomination as the First Secretary of Central Committee of the Communist Party of the Soviet Union, along with comrade Hysni Kapo went to Moscow and we asked for a meeting with soviet leaders to talk about the economic problems that they did not solve" (Hoxha, 1980). During this visit, in 1954, the Soviet government sent a letter to Albanian 
government, which was led to the Communist Party central committees. Its content talks about the revision of relations between Soviet Union and Yugoslavia. According to the soviets, Yugoslav leaders have declared recently that they were ready to improve relations with Communist countries. "In the opinion of Central Committee of the Communist Party of the Soviet Union, from the socialist camp interests, would be no reason to ignore these statements and not to lead in possibilities of improving the relations with Yugoslavia, to enforce the influence peace and democracy" (Central State Archive, 1954). The Albanian leaders would not like all this at all, because they had many unsaid things about the policy that the leading part of Yugoslavia followed.

From 1954 to 1956 Soviet Union made some steps ahead becoming closer to Yugoslavia. When Soviet Union sent a resolution in 1955 to the main Central Committee of the Communist Party of Albania, where it was the announcement about the visit of Khrushchev in Belgrade to put back diplomatic relations, Albania was unsatisfied. "In 1955 Khrusshchev visited Belgrade, and a year later Tito visited Moscow. The Soviet - Yugoslav reconciliation worried Tirana" (History of Albanian People, 2008). Albanian leadership compelled to circumstances made some steps ahead to improve relations with Yugoslavia too. But the events happened in Hungary in 1956 gave the opportunity to Hoxha to find a new reason to justify its policy to Yugoslavia. In fact as it is showed in central files, even relations between Yugoslavia and Soviet Union were not better at that time. Nevertheless the efforts to co - ordinate the policies of the two countries, Khrushchev and other Soviet leaders agreed with Hoxha thoughts according to the policy followed by Yugoslavia.

Despite this, Hoxha was informed that is very important to revise the relations between Soviet Union and Yugoslavia, so that the Communism Camp would be unified in the international arena. Khrushchev could not allow that a powerful country such as Yugoslavia was very closed with the western countries, because this would meant the loss of a powerful Communist country. Thus Soviet Union pretended from Enver Hoxha to improve the relations with Yugoslavia, even though .there were many problems between this two countries. "Four years later after Stalin's death, in 1957, Enver Hoxha as first secretary of the party and Mehmet Shehu as Prime Minister went in Moscow for an official visit" (Zavalani, 1998). During this visit conflicts between the two countries become even more evident and Hoxha keeps repeating that cannot have good relations between Albania and Yugoslavia. Underpressured, Hoxha is forced to change his attitude one more time. "As a reward toward the change and their attitude, the Albanian communist regime will profit big financial aids from Soviet Union" (Duka, 2007). Even though Albania's priority was to improve the relations with Yugoslavia and make efforts to achieve this, it was difficult because Albania a withdrawn in this process.

After 1955,when Khrushchev was sure about his strong position in Soviet Union Communist Party, he took the initiative called as the "destalinism" process. To summarize "Stalin's personal secretariat was dissolved, the cleaning campaign was interrupted, many political prisoners were released, the act of patriarchal and state arbitrariness began to be criticized, many efforts had been made to slow down the pressure with the West etc" (Mezini, 1999). In 1956 Enver Hoxha and Gogo Nushi visited Moscow to take part in Communist Party XX Congress, where Nikita Krushchev disapproved Stalin' s individual cult. "As the definition of N. Khrushchev: The individual cult has affected in the diffusion of distortion methods of building the party and in economical work, has caused flagrant violation of soviet democracy, a despotic administration, with different distortion, decoration of reality" (Mezini, 1999). The new policy followed by Khrushchev would not like to Hoxha at all, he considered the "destalinism" as a process that would endangered his position inside the Albanian Communism Party.

"The Albanian leaders had little choice, but to adapt themselves to the new course after the death of Stalin in 1953, but they did so slowly and hesitantly, apparently fearful that any changes in course would disrupt the tight control the party had succeeded in establishing" (FBI Documents. Soviet-Albanian Relations, 1962). Despite the dissatisfactions that Enver Hoxha had, he knew perfectly he could not openly object Soviet Union leader, so forced by the circumstances he will disapprove Stalin's individual cult and country bureaucracy. In this situation Hoxha gave up to his positions that he had, as a Minister, even later from his position as Prime Minister of the country.

The Albanian leadership expressed to end up the harmful practice of praising the Albanian leaders. "But the only critic of Hoxha's individual cult was Hoxha himself" (Smirnova, 2004) Albanian leadership began the self-criticism, but not everyone could do critics. People who criticized the Party were called and accused as anti Marxist. Many important people of the Party like Tuk Jakova, who had been fired from his position as vice Prime Minister and all the others who were a threat for E.Hoxha. So Hoxha found a new justification hence Hoxha found a new justification for the next sweeping among the Labor Party of Albania.

Meanwhile problems between two countries seem to be more evident, however Hoxha and Krushchev to propagandize the friendship between Countries of Communism camp. So "15 April 1957, during a receiving at the Albanian Embassy in Moscow, Khrushchev said he agreed with the words of "Albanian companions", in what between the two countries there were "no disputes", and neither a divergence in state, economical, partisan, ideological or international relations problems". Khrushchev was pleased because soviet points of view "in all these problems are 
adapted completely" with the Albanian's ones" (Dervishi, 2006). When Khrushchev declared this Albanian - soviet relations were good only apparently. The soviet leader understood that Hoxha wanted to be out of the soviet influence, in fact in 1957 Albanian Communist Party has started a revaluation process of Stalin' image. Krushchev did not react directly towards these events, he tried to threat Hoxha indirectly. He knew very well economical needs of Albania, so he thought that Hoxha could hardly objects him, this interruption would cost to Albania and albanians who depends economically from the Soviet Union.

Nevertheless conflicts between the two leadership, in 1959, seem that relations reached the peak when Khrushchev accepted the invitation of Hoxha to visit Albania. This was the first visit of such an important soviet leader in our country, for this reason it was considered as a big event. The reason why Khrushchev came to Albania were clear. "But more importantly, it was probably intended to provide Khrushchev the time and opportunity ho obtain a better view and understand- ing of Albania, its problems and its leaders, and to wipe away the residue of friction between the two countries" (FBI Documents. Soviet-Albanian Relations, 1962). At the beginning the two countries seem to force every day even more their friendship, but this visit would make evident the problems between the two parties. Khrushchev left Albania two days earlier than it was predicted. This rose the dissatisfactions of Albania towards Soviet Union.

Another reason which affected the gap between Albania and Soviet Union was the economic situation. During his visit Khrushchev made clear one more time to Albanians that he could not give economical help to them, so he cut systematically all economic aid to Albania. Hoxha asked to Khrushchev credit to build a textile factory and a factory to elaborate the oil. Khrushchev about this case says: " there is not much time we gave you a new credit and you said that before the five year finishes we won't ask anymore" ( Albanian Central Archive, 1949). Mehmet Shehu answered that they had given to them only 300 million. Khrushchev answered: "Why 300 million is a too little for you? Otherwise we will go tomorrow. You gave us a lunch and you ask all these things from us. This is too expensive. If we knew that we would had taken the lunch with us" (Albanian Central Archive, 1949).

Taking into account the numerous disputes between the two governments and the increasingly lack of economic aid, necessary for Albania, Enver Hoxha thought it was the right moment for a new positioning of the country in international affairs. In such a moment, finding a new ally, that would have the possibilities and the good will to replace Soviet aid was essential for the country. In fact for several years, Hoxha and other leaders of the Communist Party had found a new alternative, which would enable them to continue to govern without disconnecting from the Marxist-Leninist ideology. In 1956 Enver Hoxha visited Beijing, where the Chinese government promised to furnish Albania with the needed aid. Moreover, in 1959, relations between the People's Republic of China and the Soviet Union seemed increasingly distort. "It was in mid-October that the Albanians began clearly aligning themselves with China on controversial issues. Events surrounding the fifteenth anniversary of Albanian liberation on 28 November again pointed up the growing cleavage in Soviet-Albanian relations and the increasing warmth in Sino-Albanian relations"( FBI Documents. Soviet-Albanian Relations, 1962).

In May 1960 an Albanian delegation consisting of Gogo Nushi, Haxhi Lleshi and Liri Belishova visited China, confirming the position that the CPA would hold against Chinese-Soviet conflict. Albanian new orientation was harming the country, which had already started to feel the lack of grain coming from the SU. Many industrial works were not completed, and no matter how great China was, it could not cover all the aid that came from the Soviet Union.

Problems that had already arisen in the socialist camp became even more evident in the meeting of representatives of communist parties, held in Bucharest in June 1960. "Prior to the Bucharest Conference, between our two parties and countries there existed cordial fraternal relations which may rightly be characterized as exemplary in relationships of proletarian internationalism."(The Facts About Soviet-Albanian Relations. 1964). Enver Hoxha and Mehhmet Shehu did not participate in this meeting, but they sent Hysni Kapo as a representative of the Albanian government, who at the time held the post of Secretary to the Committee central to the CPA. "The reason given for Hoxha's absence from the Bucharest Congress of 1960 was Khrushchev's decision to force the Parties of the Soviet bloc to accept his policy of peaceful coexistence" (Forign Office Documents, 1962.). In this meeting Hysni Kapo tried to maintain a neutral stance, although in such a situation where conflicts between the SU and the People's Republic of China had reached its height, maintaining neutrality was almost impossible. The Soviet delegation asked the participating countries to criticize the Chinese Communist Party. Hysni Kapo, "after consultation with Tirana, refused to participate in the meeting, calling it necessary, that the disputes between the SU the CCP should be resolved with bilateral talks" (Smirnova, 2004) Regarding this issue, Nikita Khrushchev in his memoirs would say: "I don't remember now the name of the representative of the Albanian Party of Labor at the conference in Bucharest. But I asked him: "What's going on? He answered: "Comerade Khrushchev, I myself don't understand anything. But I have received orders to support the Chinese." (Khrusshchev, 2007)

Such objection was not going to be easily forgotten by Khrushchev, so getting support from the Soviet Union 
became every time more difficult. "Therefore, from this point, because the attitude of the representatives of the Party of Labor of Albania, was opposing the views of the delegation of the Communist Party of the Soviet Union in Bucharest Meeting, they began an open attack against the party and our country; there were efforts to damage Albanian-Soviet relations; unacceptable interference in internal affairs, political pressures, economic and military, which have been increasing day by day; unfriendly attitude of some Soviet leaders to the party and our country" (Albanian Central Archive, 1961). These were the statements that were said by the Albanian leaders.

The Albanian-Soviet conflict became public at the next meeting of the UN in September 1960. Chairman of the Albanian delegation was Mehmet Shehu, it seemed that Enver Hoxha was increasingly avoiding the confrontation with the Soviet leader, Nikita Khrushchev. In the eyes of the whole world, the communist camp was not unified as before, as the problems between the countries could not be hidden anymore. It was evident that the Soviet Union, who governed the foreign policy of all the communist camp, was not able to impose its will to those countries who already rejected it, before Yugoslavia, and recently China and Albania. "The conflict culminated in the meeting of the 81 Communist Parties in November 1960 in Moscow, when Hoxha, according to reports, denounced Khrushchev as "a traitor to the Communist idea, a weakling and a revisionist," and the Soviet leader retorted that Hoxha was going to pay for the offense." (Forign Office Document, 1962) The Albanian delegation proved to be tough in the declarations during this meeting leaving no opportunity to improve relations with the Soviet Union in the future, while the Chinese delegation was more careful in the accusations made towards the SU. "Soviet leaders tried to change the situation and asked Hoxha and Shehu a private conversation, which they categorically rejected"( Smirnova, 2004). As the speech was finished, Hoxha and the delegation he was representing left Moscow immediately, not even waiting for the end of the meeting. This would be Enver Hoxha's last visit in Moscow.

The peak of these disputes would be the conflict for the military basis of Vlora, which was built in 1957 by the Soviets. Vlora base has a favorable geographical position, it is the only such base of the socialist camp on the Mediterranean where American VI Fleet operates and where operates the main arteries of NATO for oil ( Foreing Ministry Archive of Albania, 1961), for this reason it had full attention of the Warsaw Pact and SU. But since the Bucharest meeting, the Soviet Union was not fulfilling the agreement to supply the necessary aid for the base, leaving more work unfinished. The conflict for the basis of Vlora, violated the position of Albania as a member of the Warsaw Pact.

So in the Political Consultative Committee meeting of the Warsaw Pact held in Moscow in 1961, the General Commander of the Armed Forces A. Greçko, said that he would be helped in further strengthening of the military member countries of the Warsaw Treaty (Foreing Ministry Archive of Albania, Viti 1961). Albanians thought they would benefit in providing the necessary assistance for the Base of Vlora, which were interrupted by the Soviet Union, but in reality this did not happen. The base was under the jurisdiction of the Warsaw Pact and the personnel were Soviet and Albanian. The problem, after breaking relations with the SU, stood in dividing the submarines and auxiliary equipments in the base. The Soviet Union was increasing pressure on Albania, persistently seeking to return the 12 submarines that were placed at the base of Vlore. On the other hand, Albania refuses to submit the crews and reaffirms its position that the only way for the solution is the implementation of the agreements of 12 September 1957 and 3 May 1959. Albania-Soviet relations were becoming more and more irritated, and disputes between the two governments were increasingly frequent. Enver Hoxha in his work "Khrushchevites" says that Khrushchev would reflect his ideological disputes in the issue of Vlora. "It is quite clear that even in the field of military relations position was predetermined and is used only as a tool and used as leverage against our party and people, because of disagreements aroused in the Bucharest meeting." (Hoxha, 1980). To resolve this dispute Albania often approached for assistance the Forces Commander General of the States of the Warsaw Pact, A. Grecko. In correspondence with members of the Albanian government, he reaffirms the importance that this base has for Albania and all the communist Camp. On May 29, 1961, the Albanian Defense Minister Beqir Balluku, hosted a representative of the General Command of the Warsaw Pact, General-Colonel Andrejev who announced that the "Admiral Kasatonov has been in the basis for dealing with the issue of evacuation of Soviet naval forces from the base of Vlora" (Central Archive of the Armed Forces, 1961) So on 4 June 1961 the largest floating dock with 8, out of 12, submarines, under the command of Admiral Kasatonov, deserted the Albanian waters.

Therefore, the close friendship between the two countries, changed into numerous contradictions and mutual accusations between these two. According to the Soviet, the causes of deterioration of the relations between the two countries have sought to unfriendly attitude of the Albanians against the Soviets and numerous incidents that happened between them in recent years. According to the Albanians, the problems were born as a result of critical attitudes that Albanians held in the Bucharest meeting, the existence of different opinions with Khrushchev to resolve these disputes, disregard of the bilateral agreements from the SU, and above all, the deviation Hrusshov has made from the MarxistLeninist ideology. Despite these ideological differences, it was economic necessity, caused by Mosscow's failed attempts to apply economic pressure, which drove Albania into an unequal alliance with China. ( Luthi, 2008). 
1961 is the year of successive collisions between Albania and the Soviet Union, whose influence would affect the attitude of other members of the communist camp. Personal interests of the Albanian leaders guided them to a new place, unknown to them so far, China.

"After these developments, on 3 December 1961, the Soviet Union has ended the relations with Albania" (Duka, 2007) pulling even the diplomatic corps from Albania. Discontinuities of these relations would have its consequences in political and economic life of the country as well, now before Hoxha, there were new enemies that needed to be discovered and imprisoned, and that sentence did not fail to come. "In the Communist world, conflicts have to take an ideological form even when the real motives may be the interests of individuals or groups or the power politics of countries. The February 1961 Congress of the Albanian Communist Party reflected this fact clearly" (Forign Office Documents, 1962).

Meanwhile, the democratic countries were witnessing an unusual event in the communist camp, however they tried to not interfere, as they had done during the 1956 in the Hungarian revolution. The end of the Albanian-Soviet relations, was deemed a favorable situation for the West, but delicate enough to be treated and not conducive to intervene. So, Albania became part in the cycle of international relations during the Cold War. " ( Nofulla, 2013).

\section{References}

Central Archive of the Armed Forces. File. 170. 1961.

Central State Archive of Albania. (1949). Fund.14, File.19

Central State Archive of Albania. (1961). Fund.14, File.4

Dervishi, K. (2006). History of Albanian State 1912-2005. Tirana: Shtëpia Botuese"55".

Duka, V. (2007). Albanian History 1912-2000. Tirana: Shblu.

FBI Documents. Soviet-Albanian Relations. (1962) http://www.foia.cia.gov/sites/default/files/document_conversions/14/esau-19.pdf

Foreing Ministry Archive of Albania, (1961)), File. 434/3.

Forign Office Documents.(1962)

http://www.foreignaffairs.com/articles/23407/stavro-skendi/albania-and-the-sino-soviet-conflict

History of Albanian People. volume III. (2007). Tirana: Toena.

Hoxha, E. (1980) Hrushovianët. Tirana: Shtëpia Botuesë <<8 Nëntori >>

Khrushchev, S. (2007). Memories of Nikita Khrushchev: Statesman 1953-1964, Volume 3. USA: The Pensylvania State University Press.

Luthi, L. M. (2008). The Sino-Soviet Split. Princeton University Press.

Mezini, A. (1999). 20th Century Alternatives. Tirana: EFDA.

Nofulla, M. The Albanian-Soviet Split. "Diskutime” Magazine.nr. 8. Tirana: 2013.

Smirnova, N. (2004). History of Albania during the 20th Century. Tirana: ideart.

The Facts About Soviet-Albanian Relations. 1964. http://www.marxists.org/history/erol/albania/facts.pdf

Zavalani, T. (1998). History of Albania, Tirana: Phoenix \& Shtepia E Librit.

Zëri i Popullit, Newspaper, Tiranë, 3 gusht 1953, nr. 135. 